\title{
Storytelling among Lowland Scots since 1800: An All-Female, Upper-Middle-Class Family Oral Tradition in the Context of Written Tale Collections
}

\author{
CARL LINDAHL
}

In 1821, while on a summer visit to Rossie in Fife, seven-year-old Cecilia Margaret Douglas wrote home to her mother in Edinburgh describing a recent 'play day'. She named among the players a special nurse: 'Jeany Durie was also of the party[;] she is quite well and quite as pleasant as she was last year.' ${ }^{\text {'T }}$ This, with a few other lines from a later letter from Cecilia to her mother, provide the only written testimony yet found for the genesis of a family storytelling tradition spanning at least 150 years.

$\mathrm{Jeanie}^{2}$ was a riveting storyteller and a special figure for Cecilia, who listened well in her girlhood and then retold the nurse's tales long into life, sharing them with a young niece, Jemima Bannerman. Jemima, as impressed by 'Aunt Ceil's' tellings as Ceil had been by Nurse Durie's, fixed them in memory and finally wrote them down as an adult. Jemima then read the tales to her own niece, Kathleen Mary Turing Bannerman. In 1968, when Kathleen Bannerman, then in her seventies ${ }^{3}$, presented a typescript collection of five tales to the School of Scottish Studies, she was passing on a female storytelling tradition shared over four generations. Because the name of Jeanie Durie appears nowhere in the typescript, it is a tribute to the bonds formed between Jeanie and Ceil, Ceil and Jemima, and Jemima and Kathleen - and to the power of their collective love of story - that we know it today.

The 'Bannerman Manuscript', as this tale cache has come to be known, appears a modest vessel for broad speculation, yet its twenty-one typed pages are unique in ways that bear close attention. Slight as these tales are, they witness a long, unbroken tradition of female-

\footnotetext{
${ }^{1}$ This and all other quotations from Cecilia ('Ceil') Margaret Douglas are provided courtesy of her great-great-grandson, Rory Cunningham. I gratefully acknowledge his contribution not only of the letters, but also of valuable information and reflections on his family. I also express my gratitude to Anne Fisher (née Bannerman), great-great-niece of Ceil and great-niece of Jemima Campbell Lorimer (née Bannerman), who provided the photograph of Ceil's silhouette and important information on the Douglases and memories of the Bannermans. Cecilia Margaret Douglas was born 10 September 1813; her letter to her mother is dated 17 July 1821.

${ }^{2}$ In a later letter, Cecilia spelled Nurse Durie's name, 'Jeanie'; as that spelling accords more with standard usage, it will be used in all future references to the nurse.

${ }^{3}$ Kathleen Mary Turing Bannerman was born 16 April 1897 on Dean Park Crescent, Edinburgh. Her great-aunt Cecilia died in Belfast 7 February 1898, when Kathleen was 10 months old.
} 


\section{CARL LINDAHL}

international folktales in Scots that we can attribute to any one nineteenth-century Lowland storyteller, ${ }^{4}$ and they open up questions concerning what constitutes appropriate folktale editing style.

\section{Written Folktale Treatments in Early Nineteenth-Century Scotland}

In contrast to the wealth of balladry, folksong, and legendry collected in the Lowlands in the 1800s, Scottish folktales recorded in this period are peculiarly rare. Before Kathleen Bannerman presented Jeanie Durie's stories to Hamish Henderson, nearly everything we knew about Scots folktales and their performance was found in two sources, Peter Buchan's Ancient Scottish Tales and Robert Chambers' Popular Rhymes of Scotland. The collections of Buchan and Chambers - and ultimately the Bannerman Manuscript — need to be seen and assessed in light of publishing tastes and standards as they developed from Nurse Jeanie's time and into the twentieth century.

At the beginning of the nineteenth century, in Scotland and England, collectors of rhymes, ballads and folksongs were rife, but there were no Scottish collectors of oral wonder tales. The stories that emerged in print were derived from chapbooks rather than from oral performance, and the stilted chapbook style persisted as the typical means of rendering oral traditional tales in printed form. But in 1804 in England, Benjamin Tabart launched his Collection of Popular Stories for the Nursery: Newly Translated and Revised from the French, Italian and old English Writers, and his books sold very well for the ensuing thirty-five years or so, presenting translations of Perrault's 'Little Red Riding Hood' and 'Blue Beard' side-byside with modernizations of 'Jack the Giant-Killer' and 'A History of Jack and the Beanstalk.' Tabart's revisions of the Jack tales, nevertheless, largely retained their chapbook flavor. What Joseph Jacobs was later to characterize as the 'flatulent phraseology of the eighteenth-century chap-books' (1892: x) dominates the opening of Tabart's 'Jack the Giant-Killer':

In the reign of the celebrated king Arthur, there lived near the Land'sEnd of England, in the county of Cornwall, a worthy farmer, who had an only son, named Jack. Jack was a boy of bold and enterprising spirit; he delighted in stories of magicians, conjurers, giants, and fairies, and used to listen with the greatest attention while his father talked of the valiant deeds of the famous knights of king Arthur's round table (Tabart ca. 1830: 136).

In this first sentence, Tabart is largely faithful to his source: he borrows the chapbook gambit of presenting a glorified, pseudo-historical, ancient past in a familiar, geographically specified place. Tabart's second sentence throws in invented references to Jack's love of story, a not-sosubtle advertisement for his own profession of written storytelling. But the language still lacks an oral flavor; a reviewer of Tabart's work pronounced that 'it recals [sic] but faintly the

\footnotetext{
${ }^{4}$ None of Peter Buchan's fourteen tales (Buchan 1908) is specifically attributed to any teller, and of the tales that Chambers presents, the most attributed to any one teller are the three that Charles Kirkpatrick Sharpe attributes to his Nurse Jenny: ('The Changeling,' Chambers 1870: 70-72; 'Whuppity Stoorie,' 1870: 72-75, and 'The Paddo,' 1870: 87-89).
} 
pleasant homeliness of the narrations which used to delight us' (Alderson 1993: 65). English storybook diction was slow to loosen up.

Then came the Grimms. The first part of their Kinder- und Hausmärchen was published in 1812. In January 1814 Jacob Grimm sent a copy to Sir Walter Scott, initiating a fruitful correspondence that was to affect the publication of traditional tales in Scotland (Dunnigan 2012; Randall 2012). The brothers were not yet a household name, but Scott was to have a hand in the popularization process. In 1819, writing in The Quarterly Review, the journal cofounded by Scott, an anonymous reviewer-identified by some as Francis Cohen and others as by Scott himself - declared, 'the most important addition to nursery literature has been effected in Germany, by the diligence of John [sic] and William Grimm.' ${ }^{5}$ The first English translations of the Grimms appeared soon thereafter, in 1823 and 1826. Edgar Taylor, a friend of Cohen's, was the translator, and like Cohen, he strove to reach an audience of children and wished to remedy the 'exclusion of works of fancy and fiction from the libraries of children' (Grimm and Grimm 1888 [1839]: iv). But Taylor also sought a nostalgic adult audience:

Popular fictions and traditions are somewhat gone out of fashion; yet most will own them to be associated with the brightest recollections of their youth. They are, like the Christmas Pantomimes, ostensibly brought forth to tickle the palate of the young, but are often received with as keen an appetite by those of graver years (Grimm and Grimm 1823: iii).

But, wrote Taylor,

... the amusement of the hour was not the translators' only object. The rich collection from which the following tales are selected is very interesting in a literary point of view, as affording a new proof of the wide and early diffusion of these gay creations of the imagination apparently flowing from some great and mysterious fountain-head, whence Calmuck, Russian, Celt, Scandinavian, and German, in their various ramifications, have imbibed their earliest lessons of moral instruction (Grimm and Grimm 1823: iv).

\footnotetext{
${ }^{5}$ Alderson (1993: 63) attributes the article to Francis Cohen, later known as Francis Palgrave, but the Quarterly Review Archive (Cutmore 2005: http://www.rc.umd.edu/reference/qr/index/41.html), while acknowledging the tradition of assigning the piece to Cohen, states that the attribution is without evidence. Chambers' later editions of Popular Rhymes of Scotland (1847: 238; 1870: 89) cite the article and attribute it to Walter Scott. Indeed, the content of the article (which at one point quotes Scott [Anonymous 1819: 92]) and the opinions expressed in it closely parallel statements made by Scott in his letters to Jacob Grimm in 1814 (cf. Dunnigan 2012) and Edgar Taylor in 1823 (Grierson 1932-37: 7, 310-13). As Chambers knew Scott and was familiar with Scott's work on folklore, his attribution deserves to be tested with a close stylistic and content analysis, which is beyond the scope of the present article. The title of the article spells 'Lilliputian' as Swift does, though Tabart's book actually drops an ' 1 ': 'Liliputian.'
} 


\section{CARL LINDAHL}

Taylor, then, was writing with two audiences in mind. In his notes, he shows appreciation for the Grimms' attempts to simulate an oral style; for example, in commenting on the dialect of 'The Fisherman and His Wife,' he likens it to Lowland Scots (Alderson 1993: 65). Nevertheless, Taylor himself maintains a distanced storybook style that folklorist William John Thoms judged lacking in oral character (Alderson 1993: 65, 75n4).

Taylor sent a copy of his first translation to Scott, who responded with encouragement to all the major points of his agenda (Grimm and Grimm 1868: 334-35). From a scholarly perspective, Scott shows fascination with the occurrence of such stories across cultures; and, from a parent's perspective, he praises their power to engage children in positive ways and finds fault with contemporary nursery literature that threatens to displace the old tales:

Independently of the curious circumstances that such tales should be found existing in very different countries and languages, which augers a greater poverty of human invention than we would have expected, there is also a sort of wild fairy interest in them, which makes me think them fully adapted to awaken the imagination and soften the heart of childhood than the good-boy stories which have been in later years composed for them. (Grimm and Grimm 1868: 334-35).

Scott also commended the vernacular 'simplicity' of Taylor's translation:

I have often wished to see such a work undertaken by a gentleman of taste sufficient to adapt the simplicity of the German narratives to our own, which you have done so successfully (Grimm and Grimm 1868: $334)$.

Scott reveals here that he has clearly read, and also read aloud to his children, the book that Jacob Grimm had sent him a decade before:

When my family were at the happy age of being auditors of fairy tales, I have very often endeavoured to translate to them, in such an extempore manner as I could, and I was always gratified by the pleasure which the German fictions seemed to convey; in memory of which our old family cat still bears the foreign name of Hinze, which so often occurs in these little narratives. (letter dated 16 January 1823; Grimm and Grimm 1868: 334; Grierson 1932-37: 7, 310-11).

Most important for the fate of folktale publication in Scotland, the translated Grimm stories move Scott to recall stories he had heard when very young, and he volunteers to send his versions to Taylor:

In a great number of these tales I can perfectly remember the nursery stories of my childhood, some of them distinctly, and others like the memory of a dream. Should you ever think of enlarging your very interesting notes, I would with pleasure point out to you such of the tales as I remember. 
Scott then writes out a summary of 'Prince Paddock,' his family's analogue to the first tale in the Grimms' collection, 'The Frog King':

The Prince Paddock was, for instance, a legend well known to me; where a princess is sent to fetch water in a sieve, from the well of the World's End, and succeeds by the advice of the frog, who bids her (on promise to become his bride),

'Stop with moss and clogg with clay,

And that will weize the water away.'

The frog comes to claim his bride (and to tell the tale with effect, the sort of plash which he makes in leaping on the floor ought to be imitated), singing this nuptial ditty,-

'Open the door, my hinny, my heart,

Open the door my ain wee thing,

And mind the words that you and I spak,

Down in the meadow, by the well-spring.'

(Grimm and Grimm 1868: 334).

'Prince Paddock' was to become a focal text in published Lowland folktale tradition. Versions learned in childhood by John Leyden and Charles Kirkpatrick Sharpe would become well known to folklorists by the end of the century (Chambers 1842: 52; Chambers 1847:237-38; Chambers 1870: 87-89).

In 1826, just as Taylor's second Grimm volume was going into print, and just before Peter Buchan began combing the northern countryside for tales, Chambers first published the Popular Rhymes of Scotland, which, true to its title, focused on traditional verse. But many of the rhymes had been attached to stories and, when he knew those stories, Chambers attempted to summarize them to explain the rhymes. Scott, Taylor, Cohen, and the Grimms are likely to have been exerting some influence over Chambers at this time, for he ended his preface by looking forward to a time when readers, searching their memories, would help him compile a collection of tales that embedded rhymes. At the end of the book he places 'a list, with specimens, of the classes of Rhymes which yet remain to be published,' so that 'the public at large may form some idea of the probable contents' of a later publication, and that 'certain individual readers, who happen to possess stores of such 'legendary lore" will begin "jotting down such RHYMES and TRADITIONARY ANECDOTES as may... be called to their memory' (Chambers 1826: vi-vii). Chambers' finders' list includes the category, 'Nursery Legends and Ballads,' and presents one example, 'Pippity Pew,-partly prose - a nursery Legend':

There was once a cruel mother, who murdered one of her daughters, and made a dish of meat of the body, which she gave to her husband, who devoured it. Sister Kate, the favourite of the mother, (as the murdered daughter had been of the father,) was 


\section{CARL LINDAHL}

in the secret, and rejoiced in being rid of the rivalry of her sister. The father, on eating his horrid mess, picked all the bones, and threw them, one after another, below the table, where sister Kate sat to gather them. The deceased, after some time, came back in the shape of a bird; and divulged to her father the dreadful deed, by singing as follows:-

Pippety Pew!

My mammie me slew,

My daddie me ate,

My sister Kate

Gathered a' my banes,

And laid them between twa milk-white stanes.

Sae I grew a bird, and away I flew,

Sing Pippety Pew.

Da capo

The father, enraged at the death of his favourite child, immediately killed the mother (Chambers 1826: 294-95).

There is no overblown chapbook diction in this rendition, which is nothing but a bare-bones summary, a platform for presenting the rhyme. Indeed, aside from the rhymes that Chambers was bent on collecting, he seems to have been seeking nothing more than mere facts, for in his preface, he thanks 'those to which the collection has been already indebted' for providing 'several hundred examples of original information' (Chambers 1826: vii; emphasis added). In 1826, Chambers was showing little promise as a storyteller.

As Chambers was soliciting anecdotes from all over Scotland, Peterhead native Peter Buchan began collecting in the north. Setting out in 1827, he had put together a manuscript of fourteen tales by 1829 . Like many collectors in his time, Buchan was convinced that he was salvaging the last traces of a dying art, an art that, he believed, survived exclusively in remote rural areas. In a letter dated September 24, 1827, Buchan wrote,

I have set about collecting all the Ancient Fabulous Scottish Tales, hitherto uncollected or published; and for that purpose, have employed a few old people to canvass for me in the country, where such are only to be found. They are now wearing obsolete, being discarded from the farmer's ingle cheek (Fairley 1908: $1-2)$.

Buchan's offer only hints at the identity of the narrators: in one letter, he mentions that they were 'several old people in the North Countrie' (25 September 1838; Fairley 1908: 4). His manuscript's title page implies that all of his sources were female, for he has gotten his tales 'from the recitation of the aged sybils [sic] in the North Countrie' (Buchan 1908: 11). One of the narrators was probably an 'old Highland woman', with 'a pretty good collection of auld farran Scottish Prose Tales'; Buchan states that she has given him 'a few ... and some of them 
are curious' (25 June 1831; Buchan 1908: 3). ${ }^{6}$ Parts of his collection, then, may represent a Highland, rather than a Lowland repertoire, and the fact that Buchan found the Highland woman's tales 'curious' might indicate that he perceived them to vary substantially from Lowland narrative traditions. Nevertheless, the rhymes are in Scots, and the texts constitute the earliest-collected examples of an oral Scots folktale tradition.

A second problem with Buchan's tales is their diction, which accords much more closely with chapbook language than with identifiable Scots oral styles. The opening sentence of Buchan's 'The Young Prince', for example, indulges the chapbook trope of situating the story historically and geographically among the royalty of long-ago Britain. Compare Buchan's sentence to Tabart's opening of 'Jack the Giant-Killer (p. 2, above):

When Scotland was first inhabited, it was governed by several kings, one of whom had married a princess of great virtue, who had an only son, but, she dying before he came of age, the king married another woman, but less virtuous than the former had been, as she afterwards gave proof by her cruelty to her step-son. (Buchan 1908: 18)

As Buchan was himself a printer, it seems most likely that he normalized all the storytellers' language to the stylistic standards of the popular press; in the end, his style differs little from Tabart's storybook style, and not so dramatically from Edgar Taylor's.

Buchan's tales did not impress his contemporaries. Although he offered up his previously uncollected texts in an era when the Scottish reading public delighted in folk traditions of all kinds, he could not interest anyone in printing them. His manuscript was sent to Charles Kirkpatrick Sharpe, William Motherwell, the Maitland Society, and also possibly the Edinburgh bookseller John Stevenson, ${ }^{7}$ none of whom published it or even seems to have offered Buchan encouragement to have it published. Twelve years after Buchan finished the manuscript, of one of its tales finally made its way to the verge of print. In the 1842 revision of Popular Rhymes of Scotland, Robert Chambers thanks Buchan for having 'obligingly submitted' a collection 'for use on the present occasion'. ${ }^{8}$ But even with the fourteen tales in front of him, Chambers could not bring himself to print one without recasting it. Chambers' version of 'The Red Etin' is taken from Buchan's, but a few details of Buchan's plot and most of his diction have been altered to the limits of editorial privilege to affect an oral style (cf. Bruford and MacDonald 1994: 22).

\footnotetext{
${ }^{6}$ 'Curious' is also often used by antiquarians to signify 'rare and valuable'; it was not necessarily a pejorative term in antiquarian contexts.

${ }^{7}$ Buchan's letters reveal that he sought Sharpe's help in getting the manuscript to Stevenson, but I have seen no evidence indicating that Stevenson ever saw it. See Fairley 1908: 2, letters of 4 February 1829 and 25 August 1829.

${ }^{8}$ Fairley 1908: 4-5. As Fairley points out, this note of thanks to Buchan appeared only in the 1842 edition, and was excised from subsequent editions. Nevertheless, all three editions follow 'The RedEtin' with the acknowledgment, 'The above story is from Mr Buchan's curious manuscript collection' (Chambers 1842: 58; 1847: 243; 1870: 94).
} 


\section{CARL LINDAHL}

Nearly 190 years after Buchan completed Ancient Scottish Tales, it still has not reached a popular publisher. Furthermore, only a few of the tale titles and plots from the collection have been attested in other sources in Lowland tradition. It has shown little value as a gauge of storytelling in Scots. ${ }^{9}$

\section{Popular Rhymes of Scotland: 1842, 1847, 1870}

Ironically, the most significant accomplishment of Buchan's manuscript may have been to inspire the pre-eminent nineteenth-century collection of Scots folktales. In seeking to publish his Ancient Scottish Tales, Buchan leaned most heavily upon ballad collector Charles Kirkpatrick Sharpe (1781? - 1851), and on the day that he completed his manuscript (4 February 1829), he mailed to Sharpe a special copy, 'in the manner you recommended, with a blank to every written page, for your Notes,' but Sharpe did not respond for at least fourteen months (Fairley 1908: 2). In 1838, nine years after first sending his tales to Sharpe, Buchan was still prodding him to help find well-placed people to help him market his collection. It was most likely in 1838 that Sharpe showed the Buchan tales to Chambers (cf. Fairley 1908: 5). Although Sharpe did not express pleasure with the manuscript, its tales may well have moved Chambers to publish the Scots stories that Sharpe had submitted as early as $1824,{ }^{10}$ and that Chambers had so far chosen not to print. Whatever the case, three Sharpe tales, set down in Scots, appeared in the 1842 Popular Rhymes of Scotland alongside the thoroughly re-written version of Buchan's 'The Red Etin'. ${ }^{11}$

'Fireside Nursery Stories,' the section of 14 tales that Chambers inserted in Popular Rhymes of Scotland ${ }^{12}$ in 1842, marked a major shift in the presentation of folk fiction in Scotland. The new book's two great innovations were to impart an oral flavour to the texts and to evoke the context in which they were performed. Both of these changes showed

\footnotetext{
9 Two of Buchan's tales that do resonate with tales collected later in Scotland are 'Rashen Coatie' (Buchan 1908: 29-32; ATU 510B + 511), which shares significant traits with two tales published in Chambers' last edition (1870: 66-69); and 'The Cruel Stepmother' (Buchan 1908: 25-28; ATU 706), a version of 'The Maiden without Hands' tale that includes the 'thorn in the king's foot' motif well known in Scottish Traveller tradition, as well as in many Irish Gaelic tellings; see, for example, Williamson and Williamson 2000: 266-87; and Stewart 2000.

${ }^{10}$ See letters sent by Sharpe to Chambers in April and June 1824; Allardyce 1888: 2, 293, 305.

${ }^{11}$ Sharpe had discussed Nurse Jenny and her 'Paddo Song' as early as April 1824, two years before the first edition of Popular Rhymes of Scotland. He was probably referring to the rhymes uttered by the frog in Jenny's tale of the paddo (see note 13, below). At this point Sharpe no doubt remembered his Nurse Jenny's tales as well as the songs they contained, but in their surviving correspondence neither Chambers nor Sharpe mentions Jenny's tales (Allardyce 1894: vol. 2, 293, 305). By 1842, however, it is certain that Sharpe has submitted at least one whole tale to Chambers, for Chambers' quotes from Nurse Jenny's version of 'The Milk-White Doo' (Chambers 1842: 53, a version of ATU 720, The Juniper Tree). It may be that Sharpe's paddo and 'Milk-White Doo' texts were deciding factors in moving Chambers to elicit nursery stories for later editions of the Popular Rhymes.

${ }^{12}$ The number of stories Chambers prints is an issue of debate. In 1842 he prints 14 texts, including one variant; in 1847, 25 texts, including three variants; in 1870, 29 texts, including five variants. A number of these 'nursery tales' would, however, be classified as ballads or songs by folklorists. For example, all three editions include 'The Wee Croodlen Doo,' a ballad and version of Child 12, 'Lord Randall' (Child 1882-1898).
} 
responsiveness to the international movement that had sprouted in Scotland and England under the influence of the Grimms.

The differences between Sharpe's tales and Buchan's are dramatic. Sharpe abjures any hint of literary tradition and attempts instead to ventriloquize the woman who first told him the tales, his nurse, Jenny Blackadder. Sharpe's tale was conjured from his earliest memories, when, at age three or four, he 'would be sitting at the knee of Nurse Jenny, at his father's house in Hoddam in Dumfriesshire, about the year 1784' (Chambers 1870: 89). As printed by Chambers in 1842, Jenny's telling of the Frog Prince tale (known as 'The Walle o' the Warld's End' in earlier editions, but retitled 'The Paddo' in 1870) ${ }^{13}$ opens in a poor widow's kitchen and unfolds in a diction that would be familiar to her:

A puir widow was ae day baking bannocks, and sent her dochter wi' a dish to the walle o' the warld's end, to bring water. The dochter gaed, and better gaed, till she came to the walle at the warld's end, but it was dry. Now, what to do she didna ken, for she couldna gang back to her mother without water; sae she sat down by the side o' the walle, and fell agreeting. A Paddo then cam loup-loup-louping out o' the walle, and asked the lassie what she was greeting for; and she said she was greeting because there was nae water in the walle (Chambers 1842: 52).

In the 1842 edition of Popular Rhymes of Scotland, Chambers sets Buchan's 'The Red Etin' in the company of such heavily Scots-inflected tales as Sharpe's 'The Paddo.' For Chambers' purpose, the diction of Buchan's opening would not serve:

Near the burgh of Auchtermuchty in Fife, lived two poor widows who were unable to pay the rent of the small plot of ground allotted them by the farmer whose sub-tenants they were (Buchan 1908: 14).

So the tale was recast in diction mirroring that of Sharpe's tales, a simplified story flavoured with Scots. Here is how Buchan's first sentence was transformed:

There were ance twa widows that lived ilk ane on a small bit o' ground, which they rented from a farmer (Chambers 1842: 56).

\footnotetext{
${ }^{13}$ The same tale type was known as 'The Walle at the Warld's End' to Leyden (Chambers 1842: 52) and as 'The Prince Paddock' to Walter Scott (Grimm and Grimm 1868: 324). It is a Scottish oikotype of KHM 1, 'The Frog King' (ATU 440), famous as the tale that begins the Grimms' Kinder- und Hausmärchen. Sharpe himself identified Nurse Jenny's tale in letters as 'The Paddo's Song,' though the inclusion of 'song' in the title may have been a result of the fact that he was writing Robert Chambers to submit the piece to a collection of 'popular rhymes' (Allardyce 1888: It is very likely that Sharpe was the leading force inspiring Chambers to include tales in the 1842 edition. Chambers retitled Sharpe's tale 'The Paddo' in 1870 only after having found a different tale titled 'The Wal at the Warld's End,' which he published at the end of his section on 'Children's Fireside Tales' (1870: 105-107).
} 


\section{CARL LINDAHL}

Sharpe seems to have set the 'house style' for the 1842 edition of Popular Rhymes of Scotland, for all thirteen of the texts (and one added variant) contain at least a bit of Scots, none is overwhelmingly English in diction, ${ }^{14}$ and several are rendered in Scots from beginning to end. Some of the contributors also mirror Sharpe in trying to recreate the language of the first tellers. 'The Wee Bunnock,' for example, was contributed by 'an elderly individual, who spent his early years in the parish of Symington, in Ayrshire'; the tale

... was one of a great store of similar legends possessed by his grandmother, and which she related, upon occasion, for the gratification of himself and other youngsters, as she sat spinning by the fireside, with these youngsters clustered around her. This venerable person was born in the year 1704, and died in 1789 (Chambers 1842: 54; 1847: 234-35; 1870: 85).

Chambers, then, not only presents texts printed to look the way they would sound when spoken, but also presents the tellers, who are uniformly female, and the contexts, which are always the fireside or the nursery. ${ }^{15}$ It was not only Sharpe, but also other of Chambers' anonymous correspondents, who wrote of their nursemaids and grandmothers. The association of oral folktales with 'old wives' was immemorial, but now as the correspondents began to reunite the tales with recollections of their tellers, the nursemaids, in particular, moved to centre stage in his collection.

There was some literary precedent. Edgar Taylor's third English-language Grimm volume had appeared in 1839, and this one differed notably from its predecessors by attaching the tales to one master teller. The frontispiece of Gammer Grethel; or German Fairy Tales, and Popular Stories (Grimm and Grimm 1839) was a copy of an illustration of the Grimms' star narrator, Dorothea Viehmann, here rechristened as a granny. The growing popularity of the Grimms in Scotland and England may have had a hand in influencing Chambers to regroup the Popular Rhymes around the magnetic figure of the old-time nursemaid, though the major influence must have been the handful of contributors who vividly recollected and strove to recreate the performances of their nursemaids. Gammer Grethel seems to have seized the English imagination, and likely the Scottish as well, for in the first half of the nineteenth century Taylor's translations of the Grimms sold far better in England than the Kinder- und Hausmärchen was selling in Germany (Bottigheimer 1993: 84).

\footnotetext{
${ }^{14}$ Although some of the tales have no more than a slight dusting of Scots, Scots exerts a general effect on the entire collection. The one variant that almost entirely lacks Scots is 'The Red Bull of Norroway,' which appeared in the 1847 and 1870 editions. Chambers offers a bit of an apology in both, stating that the tale 'has reached the editor in a more English form' than 'The Black Bull of Norroway,' which precedes it (Chambers 1847: 248; 1870: 99).

${ }^{15}$ The only exception, one that reinforces the rule, does not occur until the 1847 edition, with its new tale, 'The Marriage of Robin Redbreast' (212-13). Chambers identifies the performer as Robert Burns, and the correspondent is Mrs Begg, his sister. Burns told it 'to the younger members of his father's household', and Mrs Begg, part of the audience, believes that Burns 'made it for their amusement'. Fraternal and paternal storytelling may have been quite common, but only Robert Burns seems to be able to break the stereotypical mould of granny-or-nanny-to-child transmission.
} 


\section{STORYTELLING AMONG LOWLAND SCOTS SINCE 1800}

Chambers' 1842 edition also invokes the figure of the nursemaid as an organizing principle for the two major sections devoted to children's rhymes and stories. It is arguable that Popular Rhymes of Scotland came to serve, above all, as an homage to the shadowy figure of the nursemaid. Chambers begins the section 'Rhymes of the Nursery' by praising the nurse as the figure most responsible for educating Scottish children in their cultural heritage, and he sees post-1800 changes in childrearing as damaging to that tradition:

Nothing has of late been revolutionised so much as the nursery. The young mind was formerly cradled amidst the simplicities of the uninstructed intellect; and she was held to be the best nurse who had the most copious supply of song, and tale, and drollery at all times ready to soothe and amuse her young charges. There were, it is true, some disadvantages in the system; for sometimes superstitious terrors were implanted, and little pains was [sic] taken to distinguish between what tended to foster the evil, and what tended to elicit the better feelings of infantine nature. Yet the ideas which presided over the scene, and rung through it all day in light gabble and jocund song, were really simple ideas, often even beautiful, and unquestionably suitable to the capacities of children (1842: 44; 1847: 174; cf. 1870:11).

Chambers then asserts that childrearing in more recent times stresses 'realism and right-down earnest', but such traits might not 'be so well adapted to the early state of the faculties' and that the current system 'almost entirely overlooks that there is such a thing as imagination, or a sense of fun in the human mind' (1842: 44; 1847: 174; 1870: 11-12).

There was no philosophy about these gentle dames; but there was generally endless kindness, and a wonderful power of keeping their little flock in good-humour. It never occurred to them that children were anything but children: 'bairns are just bairns,' they would say; and they never once thought of beginning to make them men and women while still little more than able to speak (1842: 44; 1847: 174; 1870:12).

Then Chambers identifies the nursemaid as the preserver of the earliest expressions of Scottish culture and decries a nursery without a nursemaid as a cause of national amnesia:

Committed as we were in those days to such unenlightened curatrixes, we might be said to go through in a single life all the stages of a national progress. We began under a superintendence which might be said intellectually to represent the Gothic age; and gradually, as we waxed in years, and went to school and college, we advanced through the fourteenth and sixteenth centuries; finally coming down to the present age, when we adventured into public life. By the extinction of the old 


\section{CARL LINDAHL}

nursery system some part of this knowledge is lost (1842: 44; 1847: 174-

75; 1870: 12).

Chambers added a few more words of praise for the vanished nurses to introduce the new section containing the nursery tales submitted by Sharpe and others:

What man of middle age or above it does not remember the tales of drollery and wonder which used to be told by the fireside, in cottage and in nursery, by the old women time out of mind the vehicles for such traditions? These stories were in general of a simple kind, befitting the minds which they were to regale; but, in many instances, they displayed considerable fancy, at the same time that they derived an inexpressible charm from a certain antique air which they had brought down with them from the world of their birth - a world still more primitive and rude and romantic than that in which they were told, old as it now appears to us. They breathed of a time when society was in its simplest elements, and the most familiar natural things were as yet unascertained from the supernatural (Chambers 1842: 51; cf. Chambers 1847: 202; Chambers 1870: 48).

Thus, Chambers found in nursemaids' tales an essential part of the past - a source for nostalgia as well as a repository of an otherwise lost national history, and a means of both stimulating the imaginations and serving the needs of children - that had vanished without an adequate replacement by the mid-nineteenth century.

Chambers' words closely echo those of both Edgar Taylor and Walter Scott (cf. pages 4-6, above; cf. Alderson 1993: 62-65); both had looked hopefully to fairy tale literature as marking the beginning of an 'aera when our children shall be allowed once more to regale themselves with the mild food which will enliven their imaginations, and tempt them on through the thorny paths of education' (Taylor, quoted in Alderson 1993:64).

In its attempt to render tales in the vernacular, and its attention to context, the 1842 'Fireside Nursery Tales' was strikingly innovative_obviously, as compared to the Popular Rhymes of 1826, and even when compared to Chambers' own 'New Edition' of 1870. A view of the contributions of Charles Kirkpatrick Sharpe to each volume reveals the extent of Chambers' debt to him.

By the time Chambers published the 1826 Rhymes Sharpe had been sending him folktales in Scots for at least two years. Chambers had culled the rhymes from these texts, but had persisted in writing the framing narrative in a standard, summarizing style. A glaring example is 'Pippity Pew', quoted in its entirety above (pp. 8-9). Only the rhymes are in Scots; the condensed prose gives no hint of oral style, but Chambers reveals Sharpe's contributions indirectly, in an 1842 footnote to 'The Milk-White Doo':

Our Annandale authority-Nurse Jenny Blackadder-had a different version .... It represented Kate as sitting under the table, and, 'aye as the gudeman threw the banes to the cat, she catched them' (1842: 53). 
In 1826 Chambers had rejected Sharpe's Scots and written instead,

The father... picked all the bones, and threw them one after another, below the table, where sister Kate sat to gather them' (1826: 294).

In 1842, Sharpe's dialect renderings were strongest. Nurse Jenny concluded her frog tale as follows:

The lassie wasna lang o' fetching the aix ; and then the Paddo sang-

'Now chap aff my head, my hinnie, my heart,

Now chap aff my head, my ain true love ;

Remember the promise that you and I made,

Down i' the meadow, where we twa met.'

Weel, the lassie chappit aff his head, and nae sooner was that done than he startit up the bonniest young prince that ever was seen. And the twa lived happy a' the rest o' their days (1842: 52).

But after 1842 Chambers' Scots retrenched. In the 1870 edition, the 1842 rhyme is repeated identically, but some of the Scots has been reconfigured to standard English spelling:

Well, the lassie chappit aff his head; and no sooner was that done, than he started up the bonniest young prince that ever was seen. And the twa lived happy a' the rest o' their days (89).

The motive for reining in the Scots of the tales may be sales. There is evidence from Germany to suggest that the first volume of the Grimms' Kinder- und Hausmärchen (1812) greatly outsold the second (1815) at least in part because the first volume employed more standard, middle-class content, tone and diction, while the second drew more on folk atmospherics (Bottigheimer 1993: 80-81). By 1870, Chambers' Popular Rhymes had been exerting enormous influence on England, especially on the work of James Orchard Halliwell, who appropriated much of Chambers' work and even Chambers' book titles, in his own work. ${ }^{16}$ Chambers may have been trying to recapture the English market that Halliwell was building. In this market, Scots was often watered down or eliminated altogether from the tales, sometimes in the effort to claim Scottish tales themselves as essentially English. The appropriating and dismissive English attitude is reflected in Joseph Jacob's preface to English Fairy Tales:

I have also included some stories that have only been found in Lowland Scotch. I have felt justified in doing this, as of the twenty-one folktales contained in Chambers' 'Popular Rhymes of Scotland,' no less than

\footnotetext{
${ }^{16}$ Halliwell's Nursery Rhymes of England already owed much to Chambers' Popular Rhymes of Scotland, but after Chambers incorporated 'Fireside Nursery Tales' into Popular Rhymes of Scotland, Halliwell took the hint and produced a book of rhymes and tales, titling it Popular Rhymes and Nursery Tales: A Sequel to the Nursery Rhymes of England (Halliwell 1849).
} 
sixteen are also to be found in an English form. With the Folk-tale as with the Ballad Lowland Scotch may be regarded as simply a dialect of English, and it is a mere chance whether a tale is extant in one or other, or both.... In the majority of instances I have had largely to rewrite these Fairy Tales, especially those in dialect, including the Lowland Scotch (Jacobs 1892: ix-x).

In paring down his use of dialect but nevertheless retaining some minimal markers of Scots, Chambers may have been attempting to assert his patriotism and bolster his sales simultaneously. In any case, the famous New Edition of 1870 serves to this day as the major anthology of Lowland Scots folktales.

Over time Chambers came to value the tales and the image of the nursemaid more and more. In the 1826 edition, The Nursery Rhymes and Nursery Tales were relegated to four pages of an addendum (293-96). By 1842, in contrast, the nursery rhymes and nursery tales each had a separate section of its own; the tales included thirteen main stories and one additional variant. In the 1847, Chambers printed 22 tales with 3 additional variants; and, finally, in the New Edition, which has become the standard (and where 24 tales and 5 variants appear) the Rhymes, with its preface in praise of nursemaids, opens the book, followed by the 'Fireside Nursery Tales'. The image of the nursemaid and the verbal art of the nursery had become the dominating traits of the book, whose title page was now illustrated with a fireside scene from one of the fireside tales, 'The Wee Bunnock'.

Although Chambers watered down some of Sharpe's dialect writing and although his attempt to render Buchan's 'Red-Etin' in Scots is largely cosmetic, he appears to have left at least four narratives untouched: the three tales of Nurse Jenny, and 'The Wee Bunnock,' contributed by an anonymous Ayrshire Correspondent. The contributors of these four tales seem to have strived mightily to render the tales exactly as they had heard them as children. As much as Chambers was influenced by the nursery philosophy of Scott and Taylor, and by the popularity of the Grimm translations, he was ultimately more deeply influenced by his most committed contributors, whose loyalty to the voices of their nursemaids helped fashion a written collection with a marked oral character. Because a significant proportion of Chambers' tales were contributed by individuals who heard them in traditional contexts and who strived to replicate the performances as accurately as their memories would permit, Popular Rhymes of Scotland significantly surpasses the published tales of the Grimms as a record of traditional storytelling in the early nineteenth century.

\section{Jeanie Durie's, Aunt Ceil's, and Niece Jemima's Stories}

Chambers and Buchan, considered together, represent a pervasive pattern in the narration and presentation of Scottish folktales. Almost without exception, the original storytellers are cited as poor females; without exception the editors, rewriters and presenters are male, and they are overwhelmingly from the middle or upper classes. In 1842, when Chambers first asked, 'What man of middle age, or above it, does not remember the tales ... 


\section{STORYTELLING AMONG LOWLAND SCOTS SINCE 1800}

told by the old women' (1842: 51; emphasis mine), he was referring to the time-frame of Ceil Douglas' birth and earliest experiences as a folktale auditor (1813 - ca. 1820).

By 1820, at the latest, Cecilia Douglas was listening to Jeanie Durie's stories. At first glance, Jeanie seems to fit perfectly the mould of the Scottish taleteller as shaped by Buchan and Chambers. She is a nurse, she lives in the countryside, and the 'pleasant' nature she assumes while participating in Ceil's play day would support Chambers' experience that nurses are typically figures of 'endless kindness', possessing 'a wonderful power of keeping their little flock in good-humour' (1842: 44).

Chambers' ideal nurse, like his own nanny, would hold that 'bairns are just bairns' ${ }^{17}$ and allow them to gorge on play; he blamed the 'revolutionised' atmosphere of the modern nursery for driving out the old-time nurses and substituting a system that treated children as adults. Yet the correspondence of seven-year-old Ceil Douglas, and some facts about her life, would seem to indicate that, on the contrary, Ceil was treated both as a child and as a young adult, and that she performed quite well in both roles.

Ceil had little choice but to grow up fast. By age seven, when she first wrote of Nurse Jeanie, her father had been dead for two years, a suicide. ${ }^{18}$ In her second and final surviving letter that mentions Jeanie Durie, written to her mother when she was thirteen or fourteen, she still has warm words for Jeanie, but Ceil is not living in a simple, child's world. Her father's death is now eight years or more in the past, and her older sister, Elizabeth (1808-1822), has now been gone for five. Ceil is her father's oldest surviving child. One of her companions has just told her, she writes, 'that I am now 'quite a woman in my appearance and very tall for a little person.' Ceil is now writing poetry about 'Queen Mary and poor Lucy' and reading it to

\footnotetext{
${ }^{17}$ In the 1870 edition, altering the 1842 introduction to 'Fireside Nursery Stories,' Chambers wrote, “'bairns are just bairns,' my old nurse would say' (1870:12).

${ }^{18}$ Anne Fisher, Cecilia's great-great-niece, has shared with me some sentences attributed to the nineteenth-century doctor, Benjamin Bell (1810-1883), whose family was close to the Douglases: The truth is that poor Lord Reston committed suicide. There was a considerable gathering of friends at Glendoick at the time of the Circuit and although he seemed rather depressed by the painful duty of having to sentence a criminal to be hanged for the first time, he gave no indication of insanity the night before. He did not appear at breakfast and John Craigie (Lord Craigie's nephew) then a young advocate, was asked to tap at his bedroom door which was separated from his own by a dressing room. Entering the latter, he found his Lordship on the floor dead with his throat cut. Dr Macfarlan from Perth came and sewed up the wound and everything was so carefully conducted that for many years the sad occurrence was known to a very few persons. Some 25 years afterwards, a man McKelvie, who had been a footman, either to Lord Reston, or at Glendoick at the time, began to send begging letters to Mrs Douglas, threatening to divulge a family secret. By firm conduct on the part of a legal friend to whom Mrs Douglas had shown these letters, this infamous procedure was brought to a close. I believe that Mrs Douglas died in ignorance of the real facts of the case, although her sons-in-law became cognisant of them'. Ms Fisher adds, 'All of this may have had some influence on the upbringing of the three surviving children and Ceil's interest in folk tales.'
} 


\section{CARL LINDAHL}

Jeanie Durie. ${ }^{19}$ After signing, 'Your most affect[ionat]e Daughter,' Ceil adds in a p.s. that she will answer her younger sister's letter 'after prayers if I have time.' 20

While we lack conclusive evidence that, in nurse Jeanie's presence, Ceil was both a little girl and a small adult, we cannot doubt that, by the time she passed Jeanie Durie's tales on to her niece Jemima, she was a grown woman who had suffered grave losses at the core of her family life. After losing her father and sister when she was very young, Ceil lost her only brother when she was 25 (and he 22), and her firstborn son at age 5 when she was 30 . She retained her memory of the nursemaid's performances through all these trying times, and in the process became the only woman narrator from the period whose tales celebrate her nursemaid, as well as the first link in an all-female line of well-educated, upper-middle-class narrators. Ceil's is the only surviving example of an

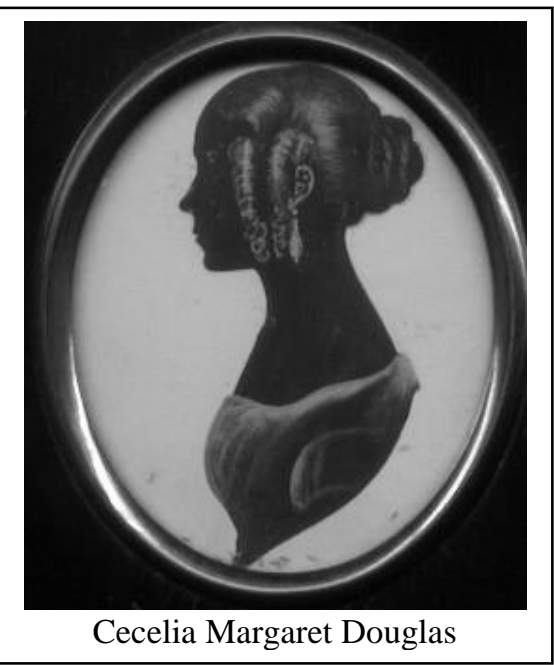

Cecelia Margaret Douglas intrafamilial nineteenth-century Scots fairy-tale tradition. We can only guess at how Ceil told the stories she received from Nurse Jeanie, but we can have no doubt that they left a deep impression on her niece, Jemima Bannerman, who in turn retold them, and around 1912 (now married and named Jemima Margaret Campbell Lorimer) wrote them down. ${ }^{21}$

Where Buchan imitated the style of contemporary chapbooks, and Chambers' correspondents sought to render the tales in Scots vernacular, Jemima adapted a turn-of-thetwentieth-century storybook style. And a storybook is evidently what she undertook to write. Peter Buchan and Robert Chambers had earlier assembled their tales with the goal of publication in mind. Jemima was no different, for the second sentence of 'A Scottish Nurse's Stories' warned its young readers that if they became frightened by the tales, their mothers 'would not buy any more of these horrid Scotch stories and that would be a pity of course, for both you and me.'

\footnotetext{
${ }^{19}$ There is no internal evidence explaining the referent for the poem about Queen Mary and 'poor Lucy'. but Cecilia's great-great niece, Anne Fisher, suggests a possible source: Lady Lucy Preston's audience with Queen Mary II, in which Lucy successfully pleaded for the life of her father, who had been imprisoned and sentenced to die for his Catholic leanings. Lucy's pleas were the subject of popular historical and artistic treatments in the nineteenth century. One of these, 'Lady Lucy's Petition,' was published in London in 1830 (Mirror 1829: 13, 293; for a full text, see Watts 1830). See also Cross 1856.

${ }^{20}$ The letter is dated 'August $20^{\text {th }} 5$ and 20 minutes to nine,' without a designated year; Rory Cunningham, who generously provided the text, estimates that it was written circa 1827, when Ceil would have been thirteen years old.

${ }^{21}$ Although Jemima died in 1929, we know that her niece Kathleen M T Bannerman remembered being fourteen or fifteen when the stories were first read to her. Kathleen was born in 1897, so the tales would have been written down by 1913 at the latest, though there is no evidence to preclude an earlier date.
} 
All three collectors altered their source stories in order to adapt them to the tastes of an audience distanced - in time, space or experience - from the contexts in which the tales were typically shared. Buchan's chapbook diction altered the performances of his sources to fit the aesthetics of the popular press. Chambers, in re-writing Buchan's 'The Red Etin'. and through other means, was trying to make his tales more accessible to his unseen readers - and to make the texts conform to a set idea of what an early-nineteenth-century nanny's storytelling style would look and sound like. ${ }^{22}$ Jemima Campbell Lorimer, having delighted in her Aunt Ceil's performances, sought to share her delight with children she would never know. Like Peter Buchan, Jemima never saw her tales popularly published in the form in which she had cast them, though, as in the case of Buchan's 'The Red Etin'. a portion of her work did eventually appear in popular anthologies in greatly altered form.

Two of Jemima's tales - the first published here for the first time and the second heavily edited when published in 1994 - convey something of the dilemmas faced by editors and readers seeking to tease a hint of the flavour of long-ago oral performances from frozen literary texts. The first of the five tales, 'A Scottish Nurse's Stories, ${ }^{23}$ signals that Jemima Campbell Lorimer is altering the family's storytelling styles to attract outsiders. In the introductory paragraph she writes, 'I will tell you a story which an old Scottish Nana used to tell to her little children long ago.' This opening is distanced and depersonalized in comparison to the family oral tradition, which identified the nurse as 'Jeanie Durie' and named 'Aunt Ceil' as the little listener who had brought the nursemaid's art to later generations of her family. In the second paragraph, as Jemima launches the tale, she immediately introduces a caricature 'Scotchman' with stereotyped status and behaviour: 'Once upon a time there was a Scotchman, who had, like many other Scotchmen, a great many children.' It is doubtful that such constant reference to a stereotype would have been part of a story shared by a Scottish nurse with an audience composed entirely of Scottish children, or have been part of a story shared by a Scottish Aunt Ceil with her Scottish niece Jemima. None of the other stories that Jemima committed to paper attempts a similar stereotyping of Scots; the fact that this is intended to be the first tale in the book, coupled with the fact that the Scotchman's tale is not given a separate title of its own, underlines the probability that it is intended as an extension of the introduction, a way of introducing a bygone storyworld to a later and much more cosmopolitan audience.

\section{A SCOTTISH NURSE'S STORIES}

\footnotetext{
${ }^{22}$ See, for example, 'The Pechs,' for which Chambers created a composite text; he states that the tale was 'made up from snatches heard from different mouths'; the implication is strong that Chambers himself was the compiler (Chambers 1847: 229-31; 1870: 80-82).

23 'A Scottish Nurse's Stories' is undoubtedly the title that Jemima intended for the entire collection. There is only one paragraph of general introduction before she launches the first tale with, 'Once upon a time' - this tale of the 'Scotchman' with many children is not assigned a separate title; it is the only one of the five tales without one, so I here identify it with the only title that precedes it, 'A Scottish Nurse's Stories.'
} 


\section{CARL LINDAHL}

Dear Children, - If I tell you this old fashioned ghost story you must promise not to be frightened. For, you know, if your mothers were to find you lying awake at night thinking you heard the ghost calling down the chimney, they would say that they would not buy any more of these horrid Scotch stories and that would be a pity of course, for both you and me. So you must remember all this happened long, long ago, before even your fathers and mothers were born, and that there is no chance of these old days coming back again, and so, of course, it would be very foolish to be frightened. Well then, if you remember that, I will tell you a story which an old Scottish Nana used to tell to her little children long ago.

Once upon a time there was a Scotchman, who had, like many other Scotchmen, a great many little children, and not very much money to give them.

Now as the children began to grow bigger he said to himself, 'I wish I had a larger house for them, for though I love them dearly, I should sometimes like a quiet place for myself, where I could smoke my pipe and read my book in peace.' And he wondered and wondered how he could get a big enough house, till at last he remembered that when he was walking in the country one day he had seen a tall old house standing quite empty, though it had a roof and windows and everything else all right. It looked indeed just as if it were waiting for someone to come in to it and make it seem alive.

'What can be the reason that no one lives in that house?' thought he, 'I shall go and ask the people to whom it belongs.' So he went to them and said, 'I wish a big house like that for my little children. How much money must I give for it?'

'Why', said the people, 'if you will be so brave as to sleep in that house and chase away the ghost which lives there, and which disturbs us all so much, we will let you have it for nothing!'

Now as you know a Scotchman, like all people, is very pleased to get something for nothing, so he said to himself, 'Here is a good chance to make a good bargain and get lots of room for my little boys and girls to play in. I shall just take that house, and as for the ghost, I do not believe it will do me any harm.'

In case, however, that the little children should be frightened he said nothing at home about the ghost, but just determined to sleep in the house himself alone first, and see what would happen. It was winter time and very cold, so he had a great fire lit in the bedroom where they said the ghost used to come, and he had a nice hot supper carried up 
there in the evening; for you know people always feel braver when they have had plenty to eat and drink, I am sure you must have noticed that? Well, there he sat for some time warming himself and eating his supper and feeling quite brave though he was all alone in the old dark house; at last he began to get so sleepy that he resolved not to watch for the ghost any longer, but just to go to bed.

I suppose he had not been asleep for very long when he was wakened by hearing a dreadful thump on the front door, and then a sound of bump, bump, bump, as if some heavy weight were being dragged up the long stone stairs. Nearer and nearer came the noise, and then, with a crash the bedroom door flew open and there, children, just think how dreadful, stood a coffin upright with a dead man inside it.

I am sure that you or I would have screamed, and hid our heads under the bedclothes, but this you see was a brave and sensible man, so he just waited quietly to see what the ghost wanted. It looked at him piteously and stretched out its cold blue fingers towards the fire crying over and over again, 'I'm cauld, I'm cauld.' 'No wonder, poor creature, in such a freezing night,' said the man to himself, 'I had better ask him to warm himself, and besides, it is always better to be civil.' So he begged the ghost to sit in the chair by the fire and warm himself and to his surprise he did so at once.

Then the ghost began his dreadful moaning cry again, only this time it was 'Oh, I'm hungry, I'm hungry.'

The man had grown bolder now, so he did not wait a minute, but asked his strange guest to have some supper; and it was a fearful sight to see how the poor creature seized on the food and tore it to pieces as if it had not had anything to eat for a long, long time, which was very likely the case.

And then, more terrifying still, he began to cry out, 'Oh, I'm weary, weary. I'm weary, weary' as if its heart would break with its longing for rest, and would you believe it, the man was so brave and kind that he actually asked the ghost to come in to his own bed and lie down and sleep there. But scarcely had he laid down when there arose a terrible wind; it went howling round the old house shaking the windows and shrieking down the chimneys as if evil spirits were abroad that night and were crying and wailing over their lost state and seeking to wreak their wicked vengeance upon some one. Louder and louder the blasts came till the man began to hear voices in the storm, and this is what they howled down the chimney. 'Rug him and rive him and fling us a blad; rug him and rive him and fling us a blad.' 


\section{CARL LINDAHL}

The dead man seemed to hear the voices too, for he sat up in bed and turned his white face to the fireplace and moaned out in answer, in a voice that rose and fell like the wind.

'Hoo-oo can I rug him, and hoo-oo can I rive him, and hoo-oo can I fling [ye $]^{24}$ a blad? Did he no bid me sit in his chair and warm me, and I wud; did he no bid me eat of his supper and I wud, and did he no bid me lie down on his bed and I wud? Sae hoo-oo can I rive him and hoooo can I rug him and hoo-oo can I fling ye a blad?'

There were then indeed terrible shrieks of rage and disappointment heard round the house, but these gradually grew fainter and fainter as the storm swept past and at last they died away into the distance.

I do not know what happened then nor did the man either, for when he came to himself again the frosty sunlight was coming in through the windows and all was peaceful and still.

After that night the ghost was never heard of again; and indeed the man's children were so merry and so noisy and filled the house so full that there would have been no peace and no room for him even if he had come.

And the moral of this story is that it is always good to be polite, and that if by any chance you ever meet a ghost you must be sure to ask him to supper. ${ }^{25}$

There are snatches of this tale, all embedded in the dialogue, that undoubtedly take us back to the first versions Ceil heard from Nurse Jeanie. Although the stereotyped 'Scotchman' speaks standard English, both the ghost who haunts him and the spirits that dog the ghost speak in Scots. The spirits chant, 'Rug him and rive him and fling us a blad,' and the ghost answers them, in appropriately ghostly diction, 'Sae hoo-oo can I rug him, and hoo-oo can I rive him, and hoo-oo can I fling ye a blad?' But this Scots speech is overwhelmed by the pervasive standard written English of an intrusive narrator. From her first words, 'Dear Children,' Jemima supplies a directorial voice. She uses warnings to advise her audience how to act ('if your mothers were to find you lying awake at night...'), preaches that 'it would be very foolish to be frightened,' intrudes with sententiae illustrating the nature of the protagonist ('Now as you know a Scotchman ... is very pleased to get something for nothing'), and uses the second person in a teacher's tone ('you know that people always feel braver when they have had plenty to eat and drink, I am sure you must have noticed that?').

\footnotetext{
${ }^{24}$ The manuscript reads, 'fling him a blad,' but as the previous dialogue and the last line of the present paragraph indicate, it is the howling spirits that wish to receive a 'blad', or morsel of the man's riven body.

${ }^{25}$ This tale is classified by folklorists as ATU 326A, Soul Released from Torment, in which a man accepts a dare to spend the night in a haunted house in return for a promised reward, which is sometimes, as in this case, the house itself. It has been collected sporadically in Scotland, although it is extremely popular in areas of the American Appalachian Mountains that were settled by Scottish and Ulster Scots immigrants.
} 
The concluding moral is both traditional and nontraditional by Chambers' standards. In Popular Rhymes of Scotland, one tale begins with a moral, one ends with a moral, and a third ends with the suggestions of a moral that Chambers (or his correspondent) cuts off abruptly: - 'Sae ye see, bairns, \&c' (Chambers 1870: 61, $85,105)$. Yet Jemima's moral differs from the three in Chambers in its dual voicing: she delivers her meaning half in earnest ('it is always good to be polite') and half in jest ('if by any chance you ever meet a ghost you must be sure to ask him to supper'). Such playful seriousness

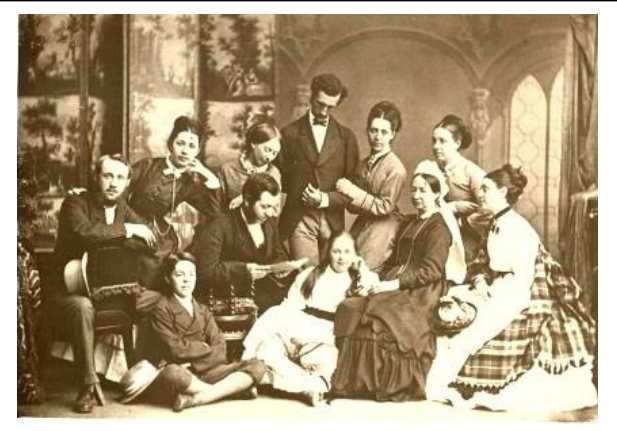

The Bannerman Family c. 1869 (Jemima back $2^{\text {nd }}$ from left ) inhabited the children's literature of late nineteenth-century England and Scotland, from Lewis Carroll to J.M. Barrie, and it would easily have penetrated into the narrative style of Jemima (Bannerman) Campbell Lorimer. In sum, with the possible exception of the moral, the addresses to the 'Dear Children' are unlikely to be either Nurse Jeanie's or Aunt Ceil's, but were probably incorporated into the tale as Jemima recomposed it for potential publication.

Together, Jemima's interactive overlays created a whole new story that did not impress late-twentieth-century folklorists. When A.J. Bruford and D.A. MacDonald set about to create an anthology of Scottish folktales that would represent the best and the most representative holdings of the Archive of the School of Scottish Studies, they selected three of Jeanie Durie's five tales for publication. ${ }^{26}$ Not surprisingly, 'A Scottish Nurse's Stories' has never been previously published in any form.

Bruford and MacDonald did, however, choose to publish 'Liver and Lights,' a rendering that undoubtedly struck them as more authentic. Yet the Bannerman Manuscript was apparently not authentic enough for Bruford, because - just as Chambers before him had recast Buchan's 'The Red Etin'-Bruford eliminated Jemima's introduction and conclusion, and made smaller changes throughout the rest of the story.

Below is the first version of 'Liver and Lights' to be published as written by Jemima Campbell Lorimer. Words from Jemima's version that were edited out by Bruford appear in italics. Other changes made by Bruford are signaled by numbers directing readers to the endnotes.

\section{LIVER AND LIGHTS}

Now I think I had better warn you that this story of the old nurse's is so shocking that you had better not read it, unless you are quite sure you will never waken in the night and think you see something

\footnotetext{
${ }^{26}$ The three published tales are 'Liver and Lights' (Bruford and MacDonald 1994: 50-51, 444n6; Tocher no. 8, 239), 'The History of Kitty Ill-Prets' (Bruford and MacDonald 1994: 185-90, 45556n21; Tocher 18: 67-71), and 'Strunty Pokes' (56-57, 461n37; Tocher 3: 82-83).
} 


\section{CARL LINDAHL}

come thrawing, thrawing through the keyhole; for then of course you would nearly die of fright and that would be a pity.

Well, the story is this:

Once $o n^{27}$ a time there was a miller, and one night after he and his wife had gone to bed, his wife took an 'awfu greening for liver and lights ${ }^{28}$, and she would not be content until her husband got up and went to the town, a little way off, to buy some.

The miller was very unwilling to go, for he was warm and comfortable in bed and it was still dark and very cold outside, but still as he was a good natured man and liked to please his wife he set out, as I have said. But on his way to the town he passed a church yard and he thought to himself, 'It is so dark and so early in the morning that I shall have to wait a long time before the shops are open in the town, besides the long way I shall have to tramp; I'll just go in here and see if I can't get liver and lights nearer home'. So he went into the church yard, and he 'howkit' up a dead body, from a newly made grave, and cut out the liver and lights from the poor corpse, and carried them home to his wife, and she not knowing where they came from, and having a greening upon her, 'she boilt them and she eated them', and was never a bit the wiser, while as for the miller you may be sure he held his tongue.

One night soon after, however, when it was dark, the miller went out to grind some corn and his wife was left alone in the house, and bye and bye ${ }^{29}$ she heard something come to the door, and then she saw the something come 'thrawing through the keyhole' and it came up to her and said:

'Is Mungo at hame?'

'No' said she, 'he's at the mill, grinding the corn and he winna be back till it's a' ground!'

Then she looked at 'It' and said: 'What wye's yere e'en sae how?'

And 'It' answered: 'Because the worms have howkit ${ }^{30}$ them oot ere $^{31}$ now.'

Then she said: 'And what wye's yere feet sae braid?'

And 'It' answered: 'Because I've traivelled, mair than e' $\mathrm{er}^{32} \mathrm{I}$ rade!'

\footnotetext{
${ }^{27}$ Bruford and MacDonald (1994: 50) read 'Once upon a time'.

${ }^{28}$ Bruford and MacDonald 1994 remove these and most other quotations in their printed version.

${ }^{29}$ The ms. reads 'by and bye'; like Bruford and MacDonald, I emend as 'bye and bye.'

${ }^{30}$ The ms. reads 'howket'; following Bruford and MacDonald, I emend as 'howkit.'

${ }^{31}$ The ms. reads 'e'er'; like Bruford and MacDonald, I emend as 'ere.'

${ }^{32}$ The ms. reads 'e're'; like Bruford and MacDonald, I emend as 'e'er.'
} 
And then she looked at 'It' again and said: 'What wye's yere puddens trailing out ahint ye?'

And then with a terrible shriek (into the listener's ear) 'It' sprang on her crying: 'Auch ye thief, ye've ate the wyte o't', and just tore her to pieces.

This is a terrible warning to us all against dishonesty and greediness, as I am sure you will all agree. ${ }^{33}$

If many aspects of the 'Scotchman' story cast doubt on the power of the Bannerman Manuscript to re-capture the nature of an underlying oral performance, 'Liver and Lights' affirms that certain elements of Jeanie's tellings have survived for nearly two centuries. About fifteen percent of the tale's verbiage is rendered in Scots, and Jemima is careful to use quotation marks to surround nearly all of these Scots expressions, which almost certainly date back to Nurse Jeanie's narration. ${ }^{34}$ The Scots of 'Liver and Lights' is uncompromising: the questions of the miller's wife and the corpse's rhyming answers offer up phrases that would likely puzzle many English readers and thoroughly dismay Joseph Jacobs: 'What wye's yere e'en sae how?' 'Ye've ate the wyte o't.' Jemima may have begun her collection thinking to sell it to readers unfamiliar with Scots, but as she worked her way through the stories, they seem to have become less for outsiders and more faithful to the family's - and thus, ultimately, to Jeanie's - tradition. Interestingly, she had gone out of her way to avoid frightening her audience in 'A Scottish Nurse's Stories' (with such lines as 'you must promise not to be frightened'); yet, as she begins 'Liver and Lights'. Jemima seems to delight in the possibility of frightening her audience: 'this story of the old nurse's is so shocking that you had better not read it, unless you are quite sure you will never waken in the night and think you see something come thrawing, thrawing through the keyhole; for then of course you would nearly die of fright and that would be a pity.' She is telling a tale that, when performed, purposely plays upon the fears of the listeners and ends with a shriek. She allows the story to overpower her intrusive voice, which simply serves to support the shock-effect of the ending.

In contrast to Jemima's version, Bruford's editing of 'Liver and Lights' misrepresents the tradition that ensured the tale's survival. The opening paragraph, omitted by Bruford, announces that the story comes from the 'old nurse' and that statement points to the obvious conclusion that the present narrator is retelling the tale. It is deceptive to omit this. It is also deceptive to remove the quotation marks that Jemima had used to identify Jeanie's speech; in offering an orthographic tribute to the nurse, Jemima was also making it easier for readers to

\footnotetext{
${ }^{33}$ This is a version of ATU 366, The Man from the Gallows, a tale reported rarely in Scotland, but much better known in areas of the United States where Scottish and Ulster Scots immigrants settled. ${ }^{34}$ The incantatory questions posed by the wife and the answers of the corpse are in thick Scots, and undoubtedly part of the nurse's original performances. The language here is so idiosyncratic and perhaps archaic that it unlikely to have been originated with either Ceil or Jemima. This is particularly true of the corpse's last words: 'ye've ate the wyte o't,' a construction so unusual that A.J. Bruford suggested it was a misunderstanding of the phrase, 'Ye aucht the wyt o't.' (Bruford and MacDonald 1994: 445); this implies that the Ceil or her niece had retained the nurse's phrase in her memory without fully understanding it.
} 


\section{CARL LINDAHL}

see how the nurse's language persisted within, and intermixed with, the performances of the upper-middle-class family that shared and transformed the tales long after Jeanie's death.

Bruford also cuts an important interpolation: the last words of the corpse to miller's wife are supposed to be shrieked 'into the listener's ear', an essential aspect of performance. In Chambers' Popular Rhymes of Scotland correspondents contributed not only the tales that they remembered, but also recollections of the narrator, the narrator's style, and certain theatrical gestures made by the narrator to enhance the performance. Thus, we learn from the anonymous contributor of 'The Cattie Sits in the Kiln-Ring Spinning' that as a child he had 'often listened with intense interest' to the tale, as his 'old nurse's acting of the story was excellent': her voice would vary from character to character, 'from the poor obsequious mouse to the surly cat,' a dramatic touch that 'carried a moral with it' (Chambers 1842: 54; 1847: 207; 1870: 54-55). Three other correspondents provide stage directions with their tales (e.g., 1847: 215-17, 219-21; 1870: 65, 70, 77); one of these tales, 'The Strange Visitor,' ends in the same manner as 'Liver and Lights,' with a dialogue between a soon-to-die mortal and the supernatural being that has come to devour her. The mortal woman asks the skeletal visitor:

[Mortal:] 'What way hae ye sic a muckle muckle head?'

[The Strange Visitor:] 'Muckle wit, muckle wit' (keenly)

'What do you come for?'

'FOR YOU!' (At the top of the voice, with a wave of the arm and a stamp of the feet.) (Chambers 1847: 217; 1870: 65).

Chambers then adds this comment:

The dialogue, towards the end, is managed in a low and drawling manner, so as to rivet the attention, and awaken an undefined awe in the juvenile audience. Thus wrought up, the concluding words come upon them with such effect as generally to cause a scream of alarm (Chambers 1847: 217; 1870: 65-66).

Both Jemima's and Chambers' texts give us a better sense than does Bruford of how such 'catch tales' were performed in nineteenth-century Scotland.

The unaltered Bannerman Manuscript reveals how two generations of one uppermiddle-class family recalled and preserved the memory of a storytelling nanny, and also how the family shaped the nanny's tales to reflect their own interests, values and tastes. The Bruford version, however, in stripping away Jemima's commentary, gives the false impression that the narrator of 'Liver and Lights' in its current form is Jeanie Durie herself. By ignoring the efforts that Jemima made to distinguish her own narrative voice from Jeanie's, Bruford ironically makes Jeanie an even more distant figure than she had appeared in 'A Scottish Nurse's Stories.'

In Ceil's last letter that mentions Jeanie Durie, the fourteen-year-old assumes an adult tone, and refers to the nurse not as a parent or grandparent figure, but as a friend:

We went the day after I came [to her hosts in Fife] to see our friends in 
Auchtermuchty, $\mathbf{M}^{\mathrm{r}}$ Leburn $^{35}$ and Jeanie Durie both of whom were very happy indeed to see me the tears gathered in poor $\mathrm{M}^{\mathrm{r}}$ Leburns eyes and he clapped me on the back most affectionately. Phemie insisted that I should read my poetry about Queen Mary and poor Lucy to him and my risible muscles were very much inclined to be rebellious when I saw the tears absolutely rolling down the poor man's cheeks at my pathetic muse, it is a tribute never before paid to it I am sure, when I finished he said every word of it would do. He seemed to like to look back upon old days and the time I first came to Rossie in short it is a pleasant thing to see people are happy to see one. We have begun the inheritance and we all like it very much even old Jeanie Durie who is here just now and forms one of our party in the old nursery, which is now dedicated to literary pursuits in short we are all very happy.... ${ }^{36}$

At this point, Ceil seems to be turning her back on storytelling. 'Old Jeanie Durie' once more joins Ceil in the 'old nursery'. but now the group is engaged in 'literary pursuits'.

In another six or seven years, Ceil would be married to a clergyman, and there were to be no references to storytelling in her later surviving letters. Nor does the married Cecilia ever mention that she once wrote poetry. Instead, she transcribed Christian hymns. Rory Cunningham writes that Cecilia's married life 'seems to have been taken up with Christian piety, her husband's domestic life, and her sister's and her children's lives. ${ }^{37}$ Yet, without the support of writing, the family storytelling went on, and the aunt-to-niece channel of transmission remained particularly strong. Anne Fisher, a great-great-granddaughter of Ceil's sister David Anne and great-great niece of Jemima, heard her aunt Day (Davie Anne Douglas Bannerman) tell stories attributed to Jemima's older sister Ata (Marie Turing Anne Bannerman). Anne writes, 'Ata was ... seven years older than Jemima and I'm sure they visited each other frequently, it was a very close knit family. Day's generation had a deep well of stories and poems that poured out from time to time, the result of no screens, radio or television and the luxury of having servants to care for them and well used leisure time.' ${ }^{38}$ Around 1946, Anne Fisher listened to Day tell a story that she'd heard as a young child around 1900, from her aunt Ata. The tale that Anne remembers is a close cousin of both of Jeanie Durie's tales published here: it features a poor tailor who accepts 'of a large sum to sew a pair o' breeks in

\footnotetext{
${ }^{35} \mathrm{Mr}$ Leyburn, who is cited as a fiddle player elsewhere in Ceil's letters, is likely Alexander Leburn of Auchtermuchty (1767-1836), who, along with his friend James Walker, composed many tunes dedicated to people whom Cecilia likely knew; e.g., 'Mrs. Cheape of Rossie's Strathspey' was dedicated to a lady of the house that Cecilia was visiting when she wrote the letters quoted here. (Leburn and Walker 2006). I am grateful to Rory Cunningham for this identification.

${ }^{36}$ Ceil's letter is dated 20 August, but no year is designated; see note 18 , above.

${ }^{37}$ Email to Carl Lindahl, 25 August 2015.

${ }^{38}$ Email to Carl Lindahl, 5 September 2015. Incidentally, Anne Fisher's grandmother, Helen, was herself an author of children's stories, one of which, 'Little Black Sambo,' became an internationally known tale (Bannerman 1899; see Hay 1981).
} 


\section{CARL LINDAHL}

the ruined chapel of Iona Abbey during the course of one night.' As he sits and sews, a skeleton assembles itself before his eyes. The tailor and the corpse engage in a series of questions and answers reminiscent of 'Liver and Lights':

By and by a pair o' braw braw feet set down on the floor beside him;

And a voice said 'See ye here these braw braw feet'

'That I see but this I sew' quo he and went on stitching the breeks.

The dialogue continues until the skeleton is complete:

By and by a great big heed, set down on the sma' sma' neck.

'See ye this great big heed?'

'That I see but this I sew' quo he and went on stitching. 'And whar gat ye

thon a muckle muckle heed? '

'Muckle wit, muckle wit'

'And what hae ye come for?'

'FOR YOU!'

The tailor put in the last stitch, gathered up the breeks and jumped through the window. He'd won the bet. ${ }^{39}$

Anne is certain that Ata's tale was strongly influenced by 'Liver and Lights.' Her family's philosophy of using oral stories, rather than moralistic storybooks, to enhance the lives of children, closely echoes the written convictions of Chambers and Scott: 'My grandmother, Helen, always said children should not be taught to read before the age of 7 as it would suppress their imagination. ${ }^{40}$ Anne Fisher's branch of this storytelling family does not, however, possess an oral tradition attributing their stories to Ceil Douglas or Jeanie Durie.

As Nurse Jeanie's stories were passing from Ceil to Jemima to Kathleen, these three generations of females were constantly engaged in social interactions that took them worlds away from the Rossie nursery. Rory Cunningham and Anne Fisher have generously shared with me letters, genealogical information, family anecdotes, and personal reflections that illumine something of the lives of these female lovers of story.

In 1821, when seven-year-old Ceil wrote home about the 'pleasant' Nurse Durie, she had already survived her father, David Douglas, Lord Reston (d. 1819), a judge and a

\footnotetext{
${ }^{39}$ Email to Carl Lindahl, 4 September 2015. This tale embodies elements common to both of Nurse Durie's tales printed here. As in 'A Scottish Nurse's Stories,' the protagonist of Aunt Ata's tale spends a night in a frightening location in return for a reward. Gaelic and Traveller versions of ATU 326A sometimes feature a tailor spending the night in a cemetery rather than a man sleeping in a haunted house. But, like 'Liver and Lights' and other versions of ATU 366, Ata's tale involves a ritual dialogue between a mortal and his supernatural nemesis.

${ }^{40}$ Email to Carl Lindahl 5 September 2015.
} 
descendent of the lairds of Strathendry, Fife. Douglas seems to have divided his time between the family estate in Fife and a home in Edinburgh. As a young man, he had also become the assistant and heir to his father's cousin, the famous economist Adam Smith (d. 1790). Smith bequeathed his library to David Douglas, so Ceil grew up surrounded by learned books when in Edinburgh, and by storytelling nurses when visiting country neighbours in Fife.

Ceil and her niece Jemima continually inhabited circles of eminence, learning, and piety. At age 20, Ceil married William Bruce Cunningham, a minister of the Church of Scotland who served in Prestonpans more or less continually for 45 years. ${ }^{41}$ William Bruce's learning also earned him election in to the Philological Society in 1861. Ceil and William's oldest surviving son, Robert Oliver Cunningham, was appointed Professor of Natural Sciences at Queen's College, Belfast. After her husband's death, Ceil seems to have moved in with her son, for she died in Belfast in February 1898.

Jemima was raised in similarly eminent surroundings. Her mother was Lord Reston's youngest and posthumous daughter, Ceil's sister, David Anne Douglas. In 1839, David Anne married James P. Bannerman, a Church of Scotland minister who would become Professor of Apologetics and Pastoral Theology at New College, Edinburgh. He, like William Cunningham, became a leader of the Free Church movement. Bannerman authored 'The Prevalent Forms of Unbelief,' 'Apologetical Theology,' and a number of other tracts. Jemima was one of six daughters in a family of nine children. ${ }^{42}$ She obviously had a special relationship with her Aunt Ceil. How many of her eight siblingss also attended and treasured Ceil's story sessions remains an open question. Jemima's niece Kate, who fell heir to the Bannerman Manuscript, continued the family tradition of education and professionalism. Her father was Jemima's brother James P. Bannerman, who, like her grandfather, Lord Reston, excelled in

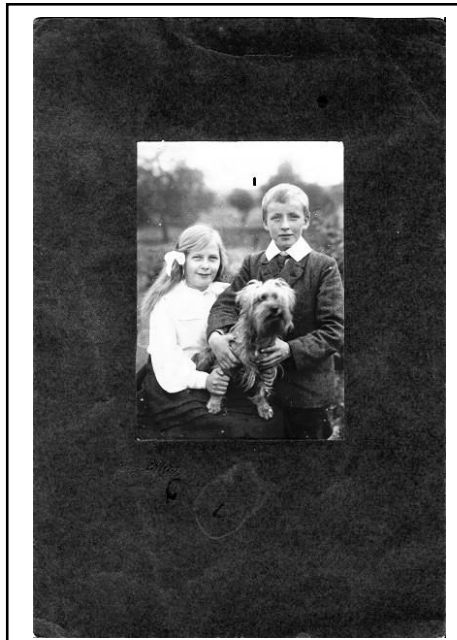

Kay and Douglas Bannerman c. 1905 the law; James was a solicitor and Writer to the Signet.

Given the accomplished history of Ceil's family, its women's devotion to Jeanie Durie's tales is all the more impressive. Demands of status and commitments to legal and educational professionalism, pervasive in all their households, kept them busy. From their

\footnotetext{
${ }^{41}$ William Cunningham was ordained a minister of the Church of Scotland, and we may assume his career was interrupted at least briefly by the schism of 1843, when he joined the group of evangelical ministers who broke away to form the Free Church of Scotland. As his great-great-grandson, Rory Cunningham, has informed me, William was declared 'No longer a minister' of his Church of Scotland parish on 24 May 1843, but he continued to practise ministry and worked with 'a large Free Church congregation until two months before his death in 1878.

${ }^{42}$ In addition to Anne Fisher and Rory Cunningham, the following sources supplied information on the family of Jemima Campbell Lorimar, née Bannerman. Matthew and Harrison 2004: Vol. 3, 71819; Stephen and Lee 1908: Vol. 1, p. 1059.
} 
earliest days the Douglas sisters, Ceil and David Anne, bore a palpably heavy burden of learning. Upon their father's tragic death (when Ceil was five and David Anne was not yet born), Adam Smith's library became their legacy, and it was eventually divided between the two sisters. ${ }^{43}$ Ceil and David Anne long survived both their father and their husbands. It was probably some time after Ceil first shared Jeanie Durie's tales with David Anne's daughter Jemima, that Ceil, now widowed, sold parts of the Adam Smith library and gave away others, ${ }^{44}$ and then likely left Scotland to live with her son, Professor Robert Oliver Cunningham, in Belfast before her death in $1898 .{ }^{45}$

Celia's letters are silent on the subject of storytelling, but we learn something of her interests through the Adam Smith books that she sold as well as those that she chose to keep. She sold the works of Newton and Voltaire, as well as the Mémoires de la Cour d'Espagne, by Madame d'Aulnay, who coined the term Conte de fées. But she hung on to the great storytellers: Homer, Boccaccio, Chaucer, Swift, and Macpherson (Bonar 1894).

Ceil was heiress both to the library of Adam Smith and to the tales of the nurse from Fife, and though she surrendered the library she clung to the stories. Jemima and Kathleen Bannerman did not inherit one of the Adam Smith books, but they treasured Jeanie Durie's tales all their lives. The three women's emotional investment in the nurse's legacy gives them the right to be remembered as traditional artists, and us the obligation to seek to understand how they experienced and transformed their tales. ${ }^{46}$

\section{REFERENCES}

\section{ALDERSON, BRIAN.}

43 Bonar 1894: vii. Bonar states, 'On Lord Reston's death the library was divided between his two daughters, Mrs. Cunningham of Prestonpans and Mrs. Bannerman of Edinburgh.' As Lord Reston had died 14 years before Ceil moved to Prestonpans and two months before David Anne was born, the library was divided much later than Bonar states; it remained with the two girls' widowed mother, Elizabeth (née Craigie) until after 1838, when Lord Reston's only son, Adam Smith Douglas, died, and 1839, when David Anne was married, and thus settled in a home that could receive the books. Rory Cunningham has communicated that a surviving letter written by Ceil to her mother in 1839 mentions the plan to divide the library between the two daughters (email to Carl Lindahl 3 September 2015).

${ }^{44}$ Bonar 1894: vii-viii.

${ }^{45}$ Rory Cunningham writes: 'It seems fairly likely that Cecilia spent her widowhood with Professor Cunningham in Belfast: I cannot find her in the 1881 census either of Scotland or of England; the 1887 letters I have indicate she was living there; I cannot find her in the 1891 census either; and she died in Belfast (on February 7 1898).' Email to Carl Lindahl 22 July 2009.

${ }^{46}$ This article is dedicated to Cecelia Margaret Douglas and all of her descendants, but especially to David Patrick Bannerman, Rory Cunningham, and Anne Fisher, who contributed their ideas, information, memories, photographs, and good will to this exploration of the storytelling traditions of their family. 
1993 "The Spoken and the Read: German Popular Stories and English Popular Diction." In Haase: 59-77.

Allardyce, Alexander. ed.

1888 Letters from and to Charles Kirkpatrick Sharpe Edinburgh: Blackwood. 2 volumes.

[ANONYMOUS]

1819 Review of Benjamin Tabart's Fairy Tales, or the Lilliputian Cabinet, Containing Twenty-four Choice Pieces of Fancy and Fiction. Quarterly Review vol 21, number 41. January. 91-112.

ATU.

2004 The Types of International Tales: A Classification and Bibliography. Based on the System of Anntti Aarne and Stith Thompson. Ed. H.-J. Uther et al. 3 vols. Helsinki.

BANNERMAN, HELEN.

1899 The Story of Little Black Sambo. London.

BONAR, JAMES.

1894 A Catalogue of the Library of Adam Smith, Author of the 'Moral Sentiments' and 'The Wealth of Nations.' London.

\section{BOTTIGHEIMER, RUTH B.}

1993 'The Publishing History of Grimms' Tales: Reception at the Cash Register.' In Haase (1993): 78-101.

BRUFORD, A.J.; AND D.A. MACDONALD (EDS.).

1994 Scottish Traditional Tales. Edinburgh.

BUCHAN, PETER (ED.)

1908 Ancient Scottish Tales: An Unpublished Collection Made by Peter Buchan. Peterhead: Reprinted from the transactions of the Buchan Field Club. http://babel.hathitrust.org/cgi/pt?id=nyp.33433086946278; view=1up;seq=13.

Accessed 8 August 2015.

CHAMBERS, ROBERT.

1826 Popular Rhymes of Scotland. [1 ${ }^{\text {st }}$ ed.] Edinburgh: William Hunter; Edinburgh: Charles Smith; London: James Duncan. http://catalog.hathitrust.org/Record/001397755 . Accessed 4 August 2015.

1842 Popular Rhymes of Scotland. $2^{\text {nd }}$ ed. Edinburgh: W. and R. Chambers. Accessed online at http://www.presscom.co.uk/chamb_1.html. Accessed 18 August 2015. 


\section{CARL LINDAHL}

1847 Popular Rhymes of Scotland. Volume 7 of Selected Writings of Robert Chambers. Edinburgh.

1870 Popular Rhymes of Scotland. New Edition. London and Edinburgh: W. and R. Chambers. http://babel.hathitrust.org/cgi/pt?id=wu.89094592573;view=1up;seq=11 Accessed 24 August 2015.

1882 - The English and Scottish Popular Ballads. 10 volumes. Boston, Massachusetts. 1898

COHEN, Francis [LATER KNOWn AS FRAnCIS PALgRAVE].

1819 Review of Benjamin Tabart's Fairy Tales, or the Lilliputian Cabinet, Containing Twenty-four Choice Pieces of Fancy and Fiction. Quarterly Review vol 21, number 41. January: 91-112.

CROSS, JOHN.

1856 Lucy Preston Pleading to Queen Mary to Save the Life of Her Father. Painting, oil on canvas. http://www.artnet.com/artists/john-cross/lucy-preston-pleading-to-queenmary-to-save-the-qXd_Wki4N3QRZfck0H0bsg2

CUTMORE, JONATHAN (ED.)

2005 Quarterly Review Archive. Published online.

http://www.rc.umd.edu/reference/qr/index.html. Retrieved 24 August 2015.

DUNNIGAN, SARAH.

2012 'The Enchanted Worlds of Scott, Scotland, and the Grimms." In Scotland and the 19 $9_{\text {th }}$ Century World, ed. Gerard Carruthers, David Goldie, and Alistair Renfrew. Amsterdam and New York: 249-74.

FAIRLEY, JOHN A.

1908 Introduction to Buchan 1908.

GRIERSON, SIR HERBERT.

1932- The Letters of Sir Walter Scott. 12 vols. London: Constable. Digital edition 37. http://www.walterscott.lib.ed.ac.uk/etexts/etexts/letters.html. Accessed 1 September 2015.

GRIMM, [J.]; AND [W.] GRIMM.

1823 German Popular Stories, Translated from the Kinder und Haus-Märchen. Collected by M. M. Grimm, From Oral Tradition. Vol 1.

1826 German Popular Stories, Translated from the Kinder und Haus-Märchen. Collected by M. M. Grimm, From Oral Tradition. Vol. 2. London, Dublin.

1868 German Popular Stories, with Illustrations after the Original Designs by George Cruikshank. Trans. Edgar Taylor. London. 
1888 German Popular Stories and Fairy Tales, as Told by Gammer Grethel. Revised

[1839] trans. by Edgar Taylor]. London.

HAASE, DONALD.

1993 The Reception of Grimms' Fairy Tales: Responses, Reactions, Revisions. Detroit: Wayne State University Press.

HALLIWELL, JAMES ORCHARD.

1849 Popular Rhymes and Nursery Tales: A Sequel to the Nursery Rhymes of England. London.

HAY, ELIZABETH.

1981 Sambo Sahib: The Story of Little Black Sambo and Helen Bannerman. $1^{\text {st }}$ ed. Edinburgh.

JACOBS, JOSEPH.

1892 English Fairy Tales. 2nd. ed. London.

KHM [Kinder- und Hausmärchen].

2003 The Complete Fairy Tales of the Brothers Grimm. Trans. Jack Zipes. $3^{\text {rd }}$ ed. New York.

LEBURN, ALEXANDER; AND JAMES WALKER.

2006 Fiddle Music from Fife. Inverness.

MATTHEW, H.C.G AND BRIAN HARRISON [EDS.].

2004 Oxford Dictionary of National Biography. From the Earliest Times to the Year 2000. Oxford.

MIRROR.

1829 Mirror of Literature, Amusement, and Instruction. Vol. 13. London.

RANDALL, LEE.

2012 'Illustrating the Brothers Grimm and Their Correspondence with Sir Walter Scott.'

The Scotsman. 19 September. http://www.scotsman.com/lifestyle/books/illustratingthe-brothers-grimm-and-their-correspondence-with-sir-walter-scott-1-2533643.

Retrieved 26 August 2015.

STEPHEN, LESLIE; AND SIDNEY LEE [EDS.].

1908 Dictionary of National Biography. Vol. 1 London.

STEWART, DAVIE.

2000. "Daughter Doris." Scottish Traditional Tales. Double CD. Cockenzie: Greentrax Scottish Tradition Series, volume 17.

TABART, BENJAMIN [ED.]. 


\section{CARL LINDAHL}

ca. Popular Fairy Tales; or, a Liliputian [sic] Library, Containing Twenty-Six Choice

1830 Pieces of Fancy and Fiction. London.

[1804]

TAYLOR, EDGAR.

1823 See Grimm and Grimm 1823. See also Grimm and Grimm 1826, Grimm and Grimm 1868, and Grimm and Grimm 1888 [1839] for other volumes introduced and translated (at least in part) by Edgar Taylor.

TOCHER

1971-

WatTs, [ PRISCILla] Mrs Alaric.

1830 "Lady Lucy's Petition.” The Casket: Flowers of Literature, Wit, and Sentiment. Philadelphia. Vol. 5: 86-88.

WILLIAMSON, DUNCAN AND LINDA WILLIAMSON.

2000 The King and the Lamp: Scottish Traveller Tales. Edinburgh. 
STORYTELLING AMONG LOWLAND SCOTS SINCE 1800

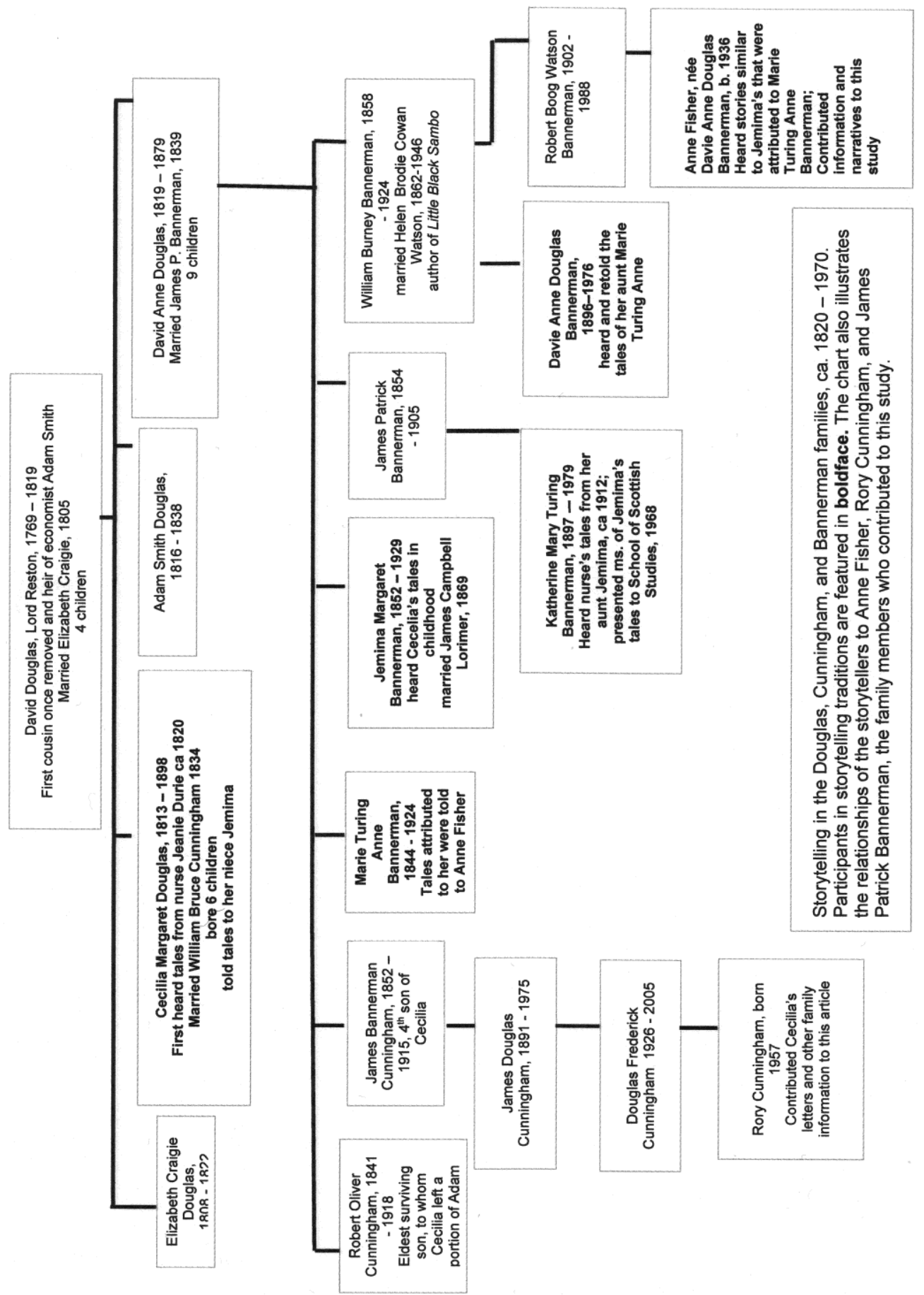

